\title{
Pelatihan Pembuatan Website Desa Wisata di Desa Wisata Meler, Kabupaten Manggarai, NTT
}

\author{
Sebastianus Menggo*1, Yosefina Rosdiana Su², Rizki Adiputra Taopan ${ }^{3}$ \\ 1,2Program Studi Pendidikan Bahasa Inggris, FKIP, Universitas Katolik Indonesia Santu Paulus Ruteng \\ ${ }^{3}$ Program Studi Agronomi, Fakultas Pertanian, Universitas Katolik Indonesia Santu Paulus Ruteng \\ *e-mail: sebastian.pradana@mail.com, josephinesu517@gmail.com², rizkimicro@gamil.com ${ }^{3}$
}

\begin{abstract}
Natural charm, cultural attractions and agro-tourism are the main objects of Meler tourism village. These tourism objects not only provide a wonderful natural persona but also a variety of traditional dances that contain historical, educational and humanistic values. These advantages can be utilized to boost the economy of rural communities. However, tourism village administrators must be digitally literate in order to maximize the economic impact of these tourism assets. The outcome target of this community service is to improve the digital literacy skills of the Meler tourist village administrators. This community service was carried out at the Meler village office for two months (May - June 2021), twice a week. A number of methods have been applied to meet the intended outcome targets, namely lecturing, questions and answers, discussions, demonstrations and presentations. The results indicate that the training participants have understood the concept of digital literacy in managing tourism villages.
\end{abstract}

Keywords: digital literacy, tourist village, training, service

\begin{abstract}
Abstrak
Pesona alam, atraksi budaya dan agro wisata merupakan obyek unggulan desa wisata Meler. Obyek tersebut tidak hanya menyuguhkan keunikan persona alam yang menakujubkan ((sawah berbentuk sarang laba-laba) tetapi juga menawarkan berbagai tarian tradisi yang mengandung nilai-nilai sejarah, edukasi dan humansitik yang universal. Keunggulan tersebut dapat dimanfatkan untuk peningkatan ekonomi masyarakat desa. Namun demikian, dampak ekonomi atas keunggulan yang dimiliki harus didukung oleh kompetensi literasi digital para pengelola desa wisata. Target capaian kegiatan pengabdian ini untuk membantu peningkatkan keterampilan literasi digital para pengelola desa wisata Meler yang berjumlah tujuh orang. Kegiatan pelatihan dilakukan di kantor desa Meler selama dua bulan (Mei - Juni 2021), dua kali dalam sepekan. Sejumlah metode telah diterapkan dalam memenuhi target capaian yang dimaksud, yaitu ceramah, tanya jawab, diskusi, peragaan dan presentasi. Hasilnya mengindikasikan bahwa, para peserta pelatihan memahami dan menerapkan konsep literasi digital dalam pengelolaan desa wisata Meler.
\end{abstract}

Kata kunci: desa wisata, literasi digital, pelatihan, pengabdian

\section{PENDAHULUAN}

Bidang pariwisata merupakan salah satu sektor yang dapat diandalkan untuk meningkatkan kesejahteraan masyarakat luas. Sejumlah wilayah di Indonesia memiliki potensi wisata yang luar biasa untuk mendukung kesejahteraan yang dimaksud, termasuk di wilayah Bali dan Nusa Tenggara. Tiga propinsi ini menyuguhkan berbagai potensi wisata unik yang walaupun belum dikelola secara maksimal. Pengelolaan obyek wisata yang baik berdampak pada roda perekonomian masyarakat luas, terutama yang berada di dekat obyek tersebut (Akan, Arslan, \& Isk, 2007; Sabon, Perdana, Koropit, \& Pierre, 2018). Sejumlah obyek wisata di tiga propinsi ini dapat mempercepat roda perekonomian masyarakat banyak dengan Bali sebagai pusat pengembangannya, yang didukung oleh potensi wisata alam, religi dan budaya di provinsi NTB dan NTT (Menggo, 2019). Atas potensi tersebut, Pemerintah Republik Indonesia menetapkan sejumlah kawasan wisata prioritas di tiga propinsi tersebut, seperti Kawasan Ekonomi Khusus (KEK) Mandalika-NTB, Kawasan Strategis Pariwisata Nasional (KSPN) Komodo-NTT, Labuan Bajo, KSPN Sanur Nusa Dua-Kuta, dan lain sebagainya (Kemenparekraf, 2015).

Perkembangan teknologi digital merupakan suatu keniscayaan. Hal tersebut berdampak pada perubahan pola pikir dan pola kerja manusia (Lankshear \& Knobel, 2016; Yazon, Ang- 
manaig, Buama, \& Tesoro, 2019). Pola kerja dengan mengandalkan teknologi non-digital dengan sendiri akan hilang karena tidak efektif dan efisien dari sisi waktu, finansial, dan lain sebagainya. Disrupsi pada era teknologi digital mendorong setiap insan untuk menampilkan daya kreatif, inisiatif dan adaptif untuk memanfaatkan berbagai peluang yang terjadi karena perkembangan teknologi digital yang terus berdampak baik pada kehidupan masyarakat luas. Teknologi digital merupakan media untuk memudahkan pola kerja manusia dengan hasil yang lebih optimal. Atas argumentasi tersebut, literasi digital merupakan salah satu varibel penting yang harus dimiliki oleh tim pengelola suatu obyek wisata. Bahwsannya, kompetensi digital tersebut dapat membantu pengembangan obyek wisata dalam mempromosikan keunikan dan keunggulan ke pangsa pasar yang lebih luas, penyebaran informasi substansial obyek wisata, serta perubahan kemasan produk wisata berbasis digital yang mutlak dibutuhkan pada masa Pandemi sekarang (Muliawanti \& Susanti, 2020).

Kompetensi literasi digital menjadi skala prioritas utama para pengelola desa wisata sebab kompetensi tersebut memberinya suatu garansi dalam memanfaatkan semua potensi wisata yang ada di desa. Aneka rintangan datang silih berganti untuk "menggoda" standar kompetensi yang telah dimiliki pengelola wisata. Akan tetapi suatu keniscayaan bagi pengelola untuk terus memeroleh keuntungan jika kompetensi yang melekat padanya mampu menempatkan suatu reaksi adaptif selaras tuntutan perkembangan pariwisata. Esensi dari reaksi tersebut tentu bermuara pada eksistensi kompetensi yang terus mendukungnya mempertahankan atau meraih prestasi gemilang dalam bidang yang digeluti, termasuk kompetensi literasi digital (Ayyildiz, Yilmaz, \& Baltaci, 2021; Radovanović et al., 2020).

Kompetensi literasi digital dan berbahasa Inggris berperan penting dalam pengembangan desa wisata (Damayanti, 2019; Jariah, 2021). Kedua kompetensi tersebut memengaruhi kemajuan dan eksistensi suatu obyek wisata. Kompentesi komunikatif bahasa Inggris membantu berkomunikasi dan menjelaskan obyek kepada wisatawan berbahasa Inggris, dan promosi suatu obyek wisata ke seluruh dunia merupakan peran penting dari kompetensi literasi digital. Oleh karena itu, pengelola desa wisata dan semua pemangku kepentingan didorong untuk mampu menampilkan kedua kompetensi tersebut, demi kelancaran dan kesuksesan pelayanan wisatawan pada setiap obyek wisata yang dimiliki desa wisata.

Desa Meler yang terletak di Kecamatan Ruteng, Kabupaten Manggarai, Propinsi Nusa Tenggara Timur, merupakan suatu desa wisata yang memiliki sejumlah daya tarik wisata. Potensi-potensi wisata yang ada di desa wisata ini, mencakup sumber daya alam, budaya, dan agro wisata. Obyek-obyek ini sangat layak dikunjungi dan dikembangkan. Para tamu tidak hanya disuguhkan dengan keindahan alam lingko Meler (sawah berbentuk sarang laba-laba) tetapi juga berbagai tarian tradisi yang mengandung nilai sejarah dan edukasi, seperti tarian tiba meka (penerimaan tamu), caci (uji ketangkasan), rangkuk alu, serta keunggulan agro wisata dengan padi, cengkeh, kopi, durian, dan aneka tanaman hortikultura sebagai objek unggulannya.

Namun demikian, berdasarkan hasil analisis kebutuhan dan diskusi awal bersama tokoh masyarakat dan aparat desa Meler dengan tim PkM pada bulan Maret 2021 mengindikasikan bahwa desa wisata Meler, Kecamatan Ruteng, Kabupaten Manggarai, Flores, Nusa Tenggara Timur masih menemukan berbagai persoalaan dalam mengelola desa wisatanya. Sejumlah permasalahan yang dimaksud, yaitu (1) efektivitas pengelolaan desa wisata yang belum berdampak pada kesejahteraan masyarakat desa, seperti transparansi pembagian keuntungan, pemanfaatan ekonomi berbasis potensi lokal, performansi budaya lokal pada kegiatan pariwisata, (2) kemasan produk wisata berbasis budaya lokal, (3) belum adanya mitra biro perjalanan wisata untuk membawa tamu ke desa wisata, (4) belum tersedianya website desa wisata, dan (5) rendahnya kompetensi komunikatif berbahasa Inggris para pengelola.

Melakukan diskusi dan analisis kebutuhan dengan peserta pelatihan merupakan langkah awal yang wajib dijalankan oleh tim pengabdi. Aanalisis kebutuhan berfungsi sebagai ruang input bagi tim pengembang modul pelatihan atau tim pengabdi masyarakat untuk mengidentiifikasi persoalan dan kebuthan nyata dari peserta pelatihan (Menggo, Par, Gunas, \& 
Guna, 2021; Menggo, Suastra, Budiarsa, \& Padmadewi, 2019). Atas argumentasi tersebut, maka tim peneliti lebih mudah menyusun isi materi pelatihan, metode pelatihan, media yang digunakan, peran peserta dan pendamping pada saat pelatihan, alokasi waktu, evaluasi kegiatan, serta peserta pelatihan lebih responsif dan kooperatif dalam kkegiatan karena semua komponen pelatihan sesuai dengan kebutuhan mereka.

Program Pengabdian kepada Masyarakat (PkM) hanya berfokus pada pelatihan pembutan website desa saja atas berbagai keterbatasan yang dimiliki tim PkM, Universitas Katolik Indonesia Santu Paulus Ruteng dan skala prioritas penyelesaian masalah yang dihadapi peserta pelatihan.Tim PkM pembuatan website desa wisata ini berjumlah tiga orang dosen, yaitu Dr. Sebastianus Menggo, Yosefina Rosdiana Su, M.Pd, keduanya berasal dari program studi pendidikan bahasa Inggris, dan Rizki Adiputra Taopan, M.Si dari program studi Agronomi. Ketiga pendamping ini dibantu oleh dua mahasiswa yang memiliki kompetensi ICT mumpuni dari Program Studi Pendidikan Bahasa Inggris, Universitas Katolik Indonesia Santu paulus Ruteng.

Berdasarkan deskripsi di atas, maka pelatihan pembuatan website desa wisata di desa wisata Meler mendesak dan urgen dilakukan.

\section{METODE}

Kegiatan PkM ini dilaksanakan di kantor desa Meler selama dua bulan, yaitu Mei-Juni 2021 dua kali dalam satu pekan (hari selasa dan jumat). Perserta yang terlibat dalam kegiatan ini adalah para pengelola desa wisata dan staf desa Meler. Pengelola desa wisata berjumlah empat orang, sedangkan staf desa berjumlah tiga orang.

Sejumlah metode dapat digunakan dalam suatu kegiatan pelatihan atau pengabdian. Metode yang digunakan disesuaikan dengan target luaran kegiatan, karateristik peserta pelatihan dan komponen pelatihan lainnya. Dalam konteks pelatihan ini, materi dan metode yang digunakan mencakup metode ceramah, belajar bersama, dsikusi kelompok, tanya jawab, peragaan atau demonstrasi, dan presentasi personal (Menggo et al., 2021; Ndiung \& Menggo, 2021). Metode-metode tersebut sejalan dengan karateristik dan target outcome kegiatan. Tabel 1 berikut merupakan contoh materi dan penerapan sejumlah metode yang dimaksud.

Tabel 1. Materi, Alokasi Waktu dan Metode

\begin{tabular}{|c|c|c|c|}
\hline Materi & Topik & Alokasi waktu & Metode \\
\hline I & $\begin{array}{l}\text { Literasi Digital dalam Pengelolaan Desa } \\
\text { Wisata: } \\
\text { a. Literasi informasi dalam pengelolaan desa } \\
\quad \text { wisata } \\
\text { b. Literasi media dalam pengelolaan desa } \\
\quad \text { wisata } \\
\text { c. Literasi ICT dalam pengelolaan desa wisata }\end{array}$ & 4 jam & $\begin{array}{l}\text { Ceramah, diskusi, dan } \\
\text { tanya jawab }\end{array}$ \\
\hline II & $\begin{array}{l}\text { Pengelolaan Website: } \\
\text { a. Domain, hosting dan website } \\
\text { b. Identifikasi sejumlah fitur dalam hosting } \\
\text { website } \\
\text { c. Langkah-langkah membuat hosting } \\
\text { d. Pembelian hosting }\end{array}$ & 6 jam & $\begin{array}{l}\text { Ceramah, diskusi, } \\
\text { tanya jawab dan } \\
\text { peragaan }\end{array}$ \\
\hline III & $\begin{array}{l}\text { Penentuan isi Website Desa Wisata Meler } \\
\text { a. Aneka fitur dalam website desa wisata } \\
\text { Meler } \\
\text { b. Isi dan narasi setiap fitur dalam website } \\
\text { desa wisata Meler }\end{array}$ & $6 \mathrm{jam}$ & $\begin{array}{l}\text { Ceramah, tanya jawab } \\
\text { dan presentasi } \\
\text { personal }\end{array}$ \\
\hline IV & Peluncuran website desa wisata Meler & 2 jam & $\begin{array}{l}\text { Diskusi dan } \\
\text { presentasi personal }\end{array}$ \\
\hline
\end{tabular}




\section{HASIL DAN PEMBAHASAN}

\section{Literasi digital dalam pengelolaan desa wisata}

Literasi digital memberi multidampak dalam bidang kehidupan manusia dewasa ini. Kemajuan teknologi digital mendorong setiap insan untuk terus beradaptasi demi mempertahankan dan memenangkan berbagai peluang usaha. Bahwasanya, setiap individu dituntut untuk mampu menampilkan keterampilan literasi digital yang memadai untuk menopang performansi usaha yang maksimal. Materi pelatihan terkait topik ini mencakup tiga komponen utama yakni, literasi informasi, literasi media, dan literasi teknologi informasi dan komunikasi dalam pengelolaan obyek wisata di desa. Ketiga literasi ini sebagai kebutuhan mandatory bagi para pelaku usaha di bidang pariwisata dalam meningkatkan efisiensi dan efektivitas usahanya. Ketiga sub-topik dari topik ini diberikan oleh tiga tutor melalui metode ceramah, diskus dan tanya jawab, seperti yang ditampilkan pada Gambar 1 berikut ini.

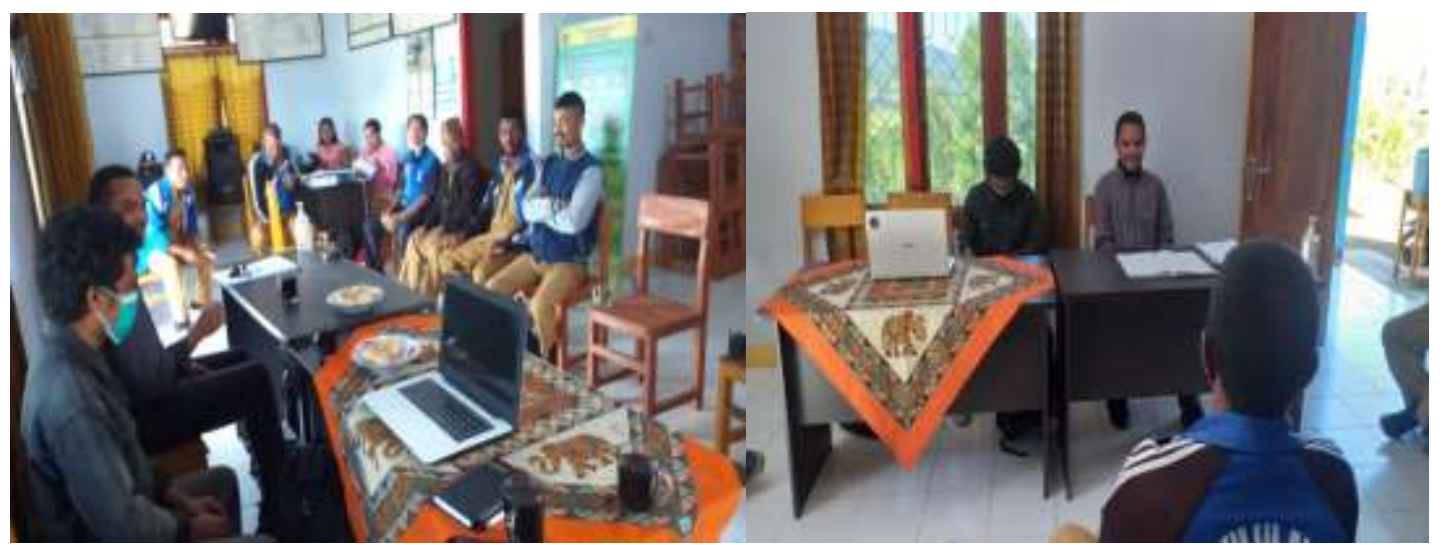

Gambar 1. Penerapan metode ceramah, diskusi dan tanya jawab dalam topik I

Kompetensi literasi digital merupakan suatu tuntutan yang harus dipenuhi oleh setiap individu pada dewasa ini, tak terkecuali para pelaku pariwisata (Jariah, 2021; Suntoro, 2020). Mereka menjelaskan bahwa literasi digital para pelaku pariwisata berperan penting dalam pengembangan dan peningkatan jumlah kunjungan wisatawan ke suatu obyek wisata. Literasi digital terdiri atas literasi informasi, media dan literasi ICT. Ketiga jenis literasi ini bersifat resiprokal dalam pengelolaan obyek wisata.

Literasi informasi, yang dipahami sebagai kemampuan untuk menemukan dan menggunakan informasi dalam kehidupan sehari-hari (Mulla, 2014). Para tutor pelatihan kegiatan mendorong peserta pelatihan untuk mampu mengakses, mengevaluasi dan menggunakan informasi sebagai rujukan dalam pengembangan obyek wisata. Literasi informasi mengarahkan peserta pelatihan untuk menjadi validator informasi pada konteks yang benar sehingga mereka tidak menyebarkan sumber informasi kepariwisataan, terutama informasi wisata desa yang tidak dapat dipertanggungjawabkan kebenarannya.

Literasi media, yang dipahami sebagai kemampuan untuk menemukan dan menggunakan media elektronik atau media cetak dalam kehidupan sehari-hari (Suryani, 2016). Dalam konteks PkM ini, para tutor mendorong peserta pelatihan memahami fungsi utama dari media digital, perangkat keras (hardware components) maupun software programs, seperti kemampuan menggunakan program MS Word, MS Excel, MS PowerPoint, video editing, web management, program scan anti virus. Literasi media yang mumpuni dapat membantu profesionalitas para pengelola wisata untuk menggelola dan mempromosikan obyek wisata ke segmen pasar yang lebih luas (Ayalew, 2016).

Literasi ICT juga mutlak dimiliki oleh para pelaku bisnis pariwisata. Dalam konteks pelatihan ini, literasi ICT, dipahami sebagai kemampuan pelaku usaha pariwisata untuk menggunakan aplikasi tertentu dalam proses pengelolaan suatu obyek wisata. Para tutor mengarahkan para 
peserta pelatihan untuk mampu menggunakan sejumlah aplikasi yang relevan dalam proses pengelolaan dan promosi obyek wisata, seperti YouTube Channel, Facebook, Twitter, WhatsApp, dan Zoom. Aplikasi-aplikasi tersebut sangat menarik dan membantu pengelolaan suatu obyek wisata untuk menjadi pengelola obyek wisata yang mandiri berbantuan aplikasi (Khatri, 2019; Pierdicca, Paolanti, \& Frontoni, 2019).

\section{Pegelolaan dan Penentuan Isi Website}

Materi cara mengelola website desa wisata sangat dibutuhkan oleh peserta pelatihan. Hal tersebut didasari oleh kemampuan peserta pelatihan pada materi tentang literasi digital, terutama pada literasi media yang diberikan pada materi pertama. Atas argumentasi tersebut para tutor dibantu oleh dua orang mahasiswa mendesain materi pelatihan yang berfokus pada keterampilan mengelola website desa wisata. Materi ini berfokus pada domain dan hosting website desa wisata Meler. Bahwasanya, para peserta masih belum paham terkait perbedaan antara domain dan hosting dalam mengelola website, sementara keduanya berperan penting dalam pengelolaan informasi suatu obyek (Afriansyah, Mubaroh, \& Pratiwi, 2020; Prijowuntato, Krissandi, \& Nugroho, 2021).

Para tutor menjelaskan secara saksama baik konsep maupun praktiknya terkait perbedaan domain dan hosting. Domain terkait dengan pemberian nama, alamat, atau legalitas nama dari suatu website, sedangkan hosting merupakan komponen yang ada dalam suatu website. Dalam konteks kegiatan pelatihan ini, nama website desa wisatanya adalah https://desawisatameler.com/ yang di dalam memiliki sejumlah hosting untuk menyimpan informasi yang relevan, seperti layanan kantor desa, layanan kesehatan, informasi pemandu wisata lokal, kolom kades, opini warga, nomor kontak, informasi tiket, galeri foto dan video promosi obyek wisata, informasi produk khas desa Meler, peta desa, informasi tempat parkir, informasi titik view obyek wisata, narasi sejumlah obyek wisata, dan masih banyak lagi. Nama website ini berdasarkan hasil kesepakatan antara para peserta pelatihan, kepala desa, dan tokoh masyarakat. Para tutor berfokus pada bagaimana peserta pelatihan memahami penggunaan sejumlah hosting yang ada dalam domain website desa wisata Meler.

Isi pada setiap fitur sesuai instruksi kepala desa berdasarkan hasil kesepakatan antara pengelola desa wisata, aparatur desa, dan tokoh masyarakat desa Meler. Kendatipun pelatihan dalam kegiatan PkM ini hanya berfokus pada pembuatan website desa wisata Meler namun sejumlah keppentingan warga desa di luar konteks wisata desa tetap diakomodir. Fitur-fitur non-informasi desa wisata, mencakup layanan kantor desa, layanan kesehatan, kolom kades, opini warga, nomor kontak, dan peta desa. Para tamu yang hendak mengunjung desa wisata Meler diberi ruang untuk mengakses terkait dengan informasi layanan kesehatan dan peta desa. Selain itu, melalui fitur opini warga, warga desa dengan mudah memberikan opini konstruktif terkait pelayanan apartur desa.

Lebih lanjut, para tutor dan mahasiswa membantu menarasikan sejumlah obyek wisata yang ada di desa wisata meler. Hal ini dilakukan karena narasi obyek sejumlah obyek wisata dilakuakn dalam dua bahasa, yaitu Indonesia dan Inggris. Sebelum diposting pada website desa wisata Meler, narasi obyek wisata yang dimaksud divalidasi lagi oleh kepala desa dan perwakilan tokoh masyarak. Gambar 2 berikut ini salah satu contoh narasi obyek tentang sawah berbentuk sarang laba-laba (rice field spider web terrace).

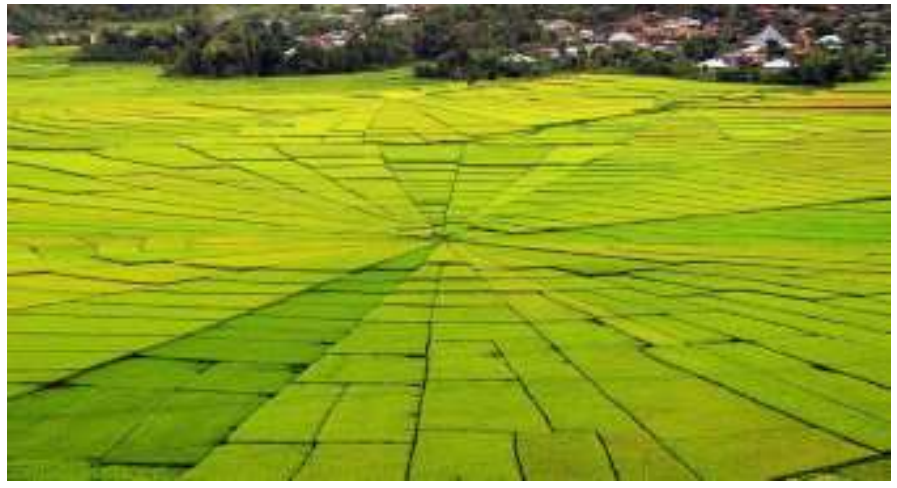

Gambar 2. Sawah berbentuk sarang laba-laba 
"Bagi warga Manggarai, keberadaan lahan pertanian sangatlah penting. Masyarakat Manggarai telah mengenal pola pertanian sejak zaman pola hidup berburu yang nomaden hingga berubah menjadi agraris. Pembagian lahan pertanian di Manggarai harus berdasarkan hukum adat. Umumnya pembagian tanah di Manggarai disesuaikan dengan bentuk sistem lingko atau lodok. Seperti halnya pembagian sawah di desa Meler dan sekitarnya. Lingko adalah istilah untuk sistem pembagian sawah yang dimulai dari titik tengah. Dari tengah, garis panjang akan ditelusuri menuju bidang terluar dari sawah yang disebut Cicing. Oleh karena itu, polanya akan tampak kecil di bagian dalam dan besar di bagian luar. Polanya lebih mirip jaring laba-laba".

\section{Peluncuran Website Desa Wisata Meler}

Setelah peserta pelatihan memahami penggunaan sejumlah hosting dalam Website desa wisata Meler, selanjutnya tutor membimbing peserta dengan memahami dan melakukan sejumlah langkah hosting, seperti analisis biaya, memasang server pada PCs operator desa wisata, uji coba server yang telah dibeli, sinkronisasi sejumlah hosting, uji coba online website, menyepakati nama website/domain. Untuk tahap pembelian hosting, peserta pelatihan dibekali dengan pengetahuan terkait dengan cara memperpanjang website, pajak tahunan website, harga paket website, persyaratan atau perlengkapan pembuatan website, dan kapasitas PCs pengelola desa wisata.

Peluncuran website desa wisata Meler secara resmi dilakukan pada akhir bulan Juni 2021. Peluncuran tersebut didasari oleh performansi para peserta pelatihan yang sudah mampu mengelola website desa wisata Meler. Para peserta menunjukkan kemampuan yang terukur terkait dengan penggunaan sejumlah hosting, pembayaran pajak, pembaharuan sejumlah hosting, editing video, design brosur informasi desa wisata, dan lain sebagainya. Peluncuran dilakuan secara blended, yaitu luring dan daring. Tim PkM bersama aparatur desa berkumpul di kantor desa, sedangkan pimpinan Universitas selaku penyedia dana PkM mengikuti peluncuran secara daring melalui aplikasi Zoom, seperti yang ditampilakn pada gambar 3 berikut ini.
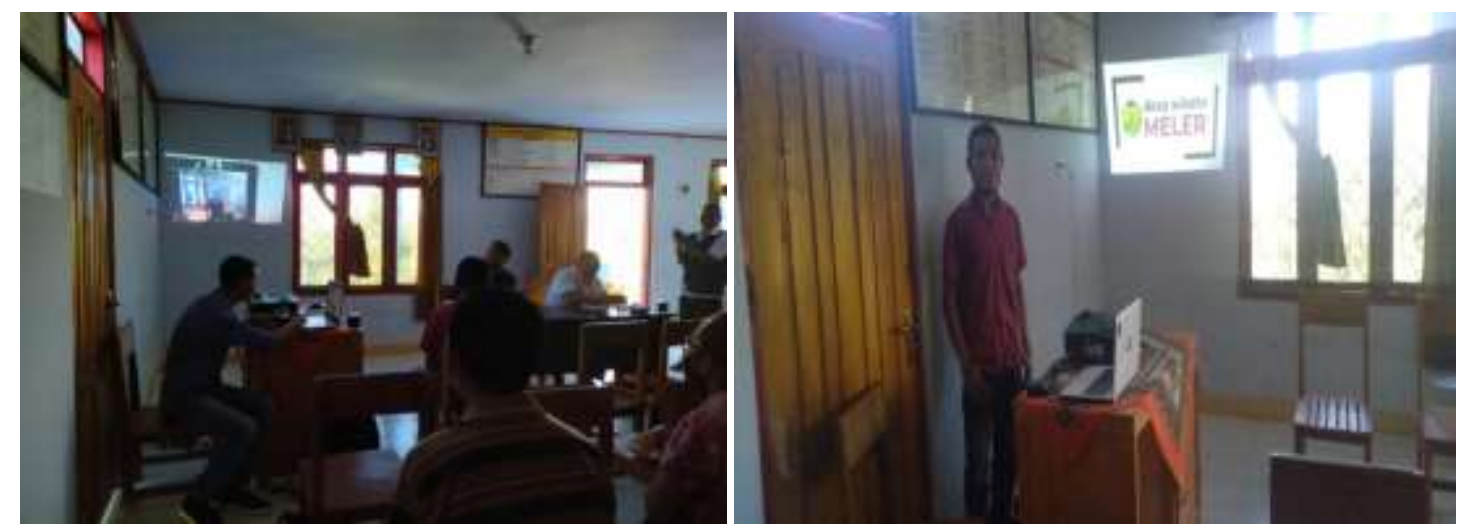

Gambar 3. Peluncuran website desa wisata Meler

\section{Evaluasi}

Evaluasi merupakan langkah terakhir dilakukan dalam kegiatan PkM ini. Evaluasi dibuat dalam bentuk lembar kuesioner dan dialog-partisipatif. Evaluasi ini berfungsi sebagai ruang refleksi bagi para tutor untuk menemukan kekurangan dan kelemahan atas kegiatan pengabdian yang telah dilakukan. Evaluasi merupakan momen refleksi bersama, sehingga ada perubahan metode, desain materi, media yang digunakan kegiatan PkM serupa pada tahap selanjutnya (Widyaastuti \& Es, 2015). Mereka menambahkan bahwa evaluasi mutlak dilakukan untuk proses perbaikan sesuai dengan target kebutuhan peserta pelatihan. Kegiatan yang telah dilakukan tidak hanya membantu peserta pelatihan memahami pengelolaan website desa wisata tetapi juga berimplikasi pada pelayanan desa yang bersandar pada media digital dalam melayani kebutuhan warga dan pengujung obyek wisata Meler.

Kepala Desa, yang mewakili peserta pelatihan dan seluruh warga desa Meler memberi ucapan limpah terimakasih dan apresiasi tak terhingga atas kegiatan pengabdian ini. Menurut 
keala Desa Meler, website desa wisata sangat dibutuhkan oleh pengelola desa wisata dan warga desa Meler secara keseluruhan. Kepala Desa menambahkan, kegiatan pengabdian ini harus dilakukan secara rutin dan desa Meler siap meneriam tim PkM dari Universitas Katolik Indonesia Santu Paulus Ruteng pada masa yang akan datang.

\section{KESIMPULAN}

Kegiatan pengabdian kepada masyarakat ini telah berkontribusi pada peningkatan kompetensi literasi digital para peserta pelatihan atau para pengelola desa wisata Meler. Kompetensi literasi digital yang dimaksud berfokus pada tiga sub-kompetensi yakni, kompetensi literasi informasi, literasi media, dan literasi teknologi informasi dan komunikasi dalam pengelolaan obyek wisata di desa. Sejummlah topik dan sub-topik telah diberikan oleh para tutor untuk mendukung ketercapaian sub-kompetensi tersebut, seperti literasi digital dalam pengelolaan desa wisata, pengelolaan website desa wisata, penentuan isi website desa wisata Meler, narasi konten sejumlah fitur atau hosting, dan diakhiri dengan peluncuran website desa wisata Meler. Metode-metode yang telah diterapkan dalam pelatihan ini mencakup metode ceramah, belajar bersama, dsikusi, tanya jawab, dan presentasi personal. Pemilihan variasi metode disesuaikan dengan karateristik peserta pelatihan dan capaian target luaran kegiatan pengabdian.

\section{UCAPAN TERIMA KASIH}

Terimakasih kepada Rektor Universitas Katolik Indonesia Santu Paulus Ruteng yang mefasilitasi kegiatan pengabdian ini, Kepala Desa Meler, atas kesediaan menerima tim PkM, peserta pelatihan, yang selalu aktif dan responsif dalam setiap pelatihan, serta mahasiswa telah membantu untuk kelancaran dan kesuksesan kegiatan ini.

\section{DAFTAR PUSTAKA}

Afriansyah, R., Mubaroh, S., \& Pratiwi, I. S. (2020). Pembuatan portal website sekolah SMA Negeri 1 Sungailiat sebagai media informasi. Dinamisia: Jurnal Pengabdian Kepada Masyarakat, 5(1), 154-160. https://doi.org/10.31849/dinamisia.v5i1.4413

Akan, Y., Arslan, I., \& Isk, C. (2007). The impact of tourism on economic growth: The case of $\begin{array}{llll}\text { Turkey. Journal } & \text { 379-388. }\end{array}$ https://doi.org/10.5367/000000007781497773

Ayalew, M. . (2016). The role of media in tourism promotion: A case study in Ethiopia. Journal of Hospitality Management and Tourism, 7(5), 50-56. https://doi.org/10.5897/JHMT2016.0177

Ayyildiz, P., Yilmaz, A., \& Baltaci, H. S. (2021). Exploring digital literacy levels and technology integration competence of Turkish academics. International Journal of Educational Methodology, 7(1), 15-31. https://doi.org/10.12973/ijem.7.1.15

Damayanti, L. S. (2019). Peranan keterampilan berbahasa Inggris dalam industri pariwisata. Journey, 2(1), 71-82.

Jariah, A. (2021). Implementasi literasi digital dalam peningkatan daya tarik wisata di era new normal Kota Palangka Raya. Jurnal Hadratul Madaniah, 8(I), 74-87.

Kemenparekraf. (2015). Rencana strategis pengembangan destinasi dan industri pariwisata tahun 2015-2019. Jakarta: Deputi Bidang Pengembangan Destinasi dan Industri Pariwisata.

Khatri, I. (2019). Information technology in tourism \& hospitality industry: A review of ten years' publications. Journal of Tourism and Hospitality Education, 9, 74-87. https://doi.org/10.3126/jthe.v9i0.23682

Lankshear, C., \& Knobel, M. (2016). Digital literacy and digital literacies: Policy, pedagogy and research consideration for education. Nordic Journal of Digital Literacy, 8-20. 
Menggo, S. (2019). English communicative competence for ecotourism speakers. In Seminar Nasional on Ecotourism (pp. 1-13). Denpasar: Warmadewa University Press.

Menggo, S., Par, L., Gunas, T., \& Guna, S. (2021). Pendampingan penyusunan soal berorientasi HOTs bagi para guru SMA. Jurnal Widya Laksana, 10(1), 14-26. https://doi.org/10.23887/jwl.v10i1.25010

Menggo, S., Suastra, I. M., Budiarsa, M., \& Padmadewi, N. N. (2019). Needs analysis of academicEnglish speaking material in promoting 21st century skills. International Journal of Instruction, 12(2), 739-754. https://doi.org/10.29333/iji.2019.12247a

Muliawanti, L., \& Susanti, D. (2020). Digitalisasi destinasi sebagai strategi pengembangan promosi pariwisata di Kabupaten Magelang. Warta Ikatan Sarjana Komunikasi Indonesia, 3(2), 135-143. https://doi.org/10.25008/wartaiski.v3i02.53

Mulla, K. R. (2014). Information literacy for students and teachers in Indian context. Pearl: A Journal of Library and Information Science, 8(2), 88-96. https://doi.org/10.5958/09756922.2014.00728.1

Ndiung, S., \& Menggo, S. (2021). Pelatihan penyusunan RPP merdeka belajar bagi guru SDN Ules kabupaten Manggarai Barat. ADIMAS: Jurnal Pengabdian Kepada Masyarakat, 15(1), 15-22.

Pierdicca, R., Paolanti, M., \& Frontoni, E. (2019). Etourism: ICT and its role for tourism management. Journal of Hospitality and Tourism Technology, 10(1), 90-106. https://doi.org/10.1108/JHTT-07-2017-0043

Prijowuntato, S. W., Krissandi, A. D. S., \& Nugroho, R. A. (2021). Pembuatan website sebagai pengenalan wisata budaya di Desa Giring. Jurnal Destinasi Pariwisata, 9(1), 33-39.

Radovanović, D., Holst, C., Belur, S. B., Srivastava, R., Houngbonon, G. V, Quentrec, E. L., ... Noll, J. (2020). Digital literacy key performance indicators for sustainable development. Social Inclusion Journal, 8(2), 151-167. https://doi.org/10.17645/si.v8i2.2587

Sabon, V. L., Perdana, M. T. P., Koropit, P. C. S., \& Pierre, W. C. D. (2018). Strategi peningkatan kinerja sektor pariwisata Indonesia pada ASEAN economic community. Esensi: Jurnal Bisnis Dan Manajemen, 8(2), 163-176. https://doi.org/10.15408/ess.v8i2.5928

Suntoro, S. (2020). Pelatihan pembuatan blog pembelajaran bagi guru sekolah dasar Punna Karya Kabupaten Tangerang. Dinamisia: Jurnal Pengabdian Kepada Masyarakat, 5(1), 47-53. https://doi.org/10.31849/dinamisia.v5i1.4569

Suryani, N. (2016). Utilization of digital media to improve the quality and attractiveness of the teaching of history. In The 2nd International Conference On Teacher Training and Education (Vol. 2, pp. 131-144). Surakarta: Sebelas Maret Universuty.

Widyaastuti, U., \& Es, D. P. (2015). Evaluasi pelatihan (training) level II berdasarkan teori the four levels Kirkpatrick. Jurnal Pendidikan Ekonomidan Bisnis, 3(2), 119-128. https://doi.org/10.21009/JPEB.003.2.1 EVALUASI

Yazon, A. D., Ang-manaig, K., Buama, C. A. C., \& Tesoro, J. F. B. (2019). Digital literacy , digital competence and research productivity of educators. Universal Journal of Educational Research, 7(8), 1734-1743. https://doi.org/10.13189/ujer.2019.070812 